\title{
Genetics of Parkinson Disease
}

\author{
Nathan Pankratz and Tatiana Foroud \\ Department of Medical and Molecular Genetics, Indiana University School of Medicine, Indianapolis, Indiana 46202-5251
}

\begin{abstract}
Summary: Parkinson disease (PD) is the second most common neurodegenerative disorder. Recent studies have consistently demonstrated that in some families, disease is attributable to a mutation in a single gene. To date, genetic analyses have detected linkage to six chromosomal regions and have identified three causative genes: PARK1 (alpha-synuclein), PARK2 (parkin), and PARK7 (DJ-1). In addition, mutations in several other genes have been implicated in familial PD. Identification of the mutations in these genes has led to the recognition that the ubiquitin-proteasome system is an important pathway that may be disrupted in PD. Studies are ongoing to identify additional genes that may contribute to PD susceptibility, particularly in late-onset families
\end{abstract}

without a clear pattern of disease inheritance. With the identification of mutations in particular genes and the likely role of additional genes that are important in PD risk-susceptibility, appropriate protocols must be developed so that accurate and informative genetic counseling can be offered to families in which one or more members has PD. Further diagnostic testing should be delayed until more is learned about the frequency, penetrance, and risk assessment of certain gene mutations. Important lessons can be learned from the implementation of counseling protocols for other neurodegenerative disorders, such as Huntington disease and Alzheimer disease. Key Words: Parkinson disease, genetics, ubiquitin-proteasome system, genetic counseling, review.

\section{OVERVIEW OF THE GENETICS OF PARKINSON DISEASE}

Parkinson disease (PD) is a common neurodegenerative disorder, second in prevalence only to Alzheimer disease (AD). The importance of genetic factors in PD etiology has been debated in the 100 years since both Gowers $^{1}$ and Leroux ${ }^{2-3}$ noted that $15 \%$ of their PD patients reported an affected family member. Analyses of a large sample of twin World War II veterans found evidence for a genetic susceptibility to PD only among twins with early-onset PD. ${ }^{4}$ The majority of other studies that have compared the familial aggregation in firstdegree and/or second-degree relatives of PD patients with that observed in the general population have found evidence for a genetic role in disease causation. ${ }^{5-8} \mathrm{Re}-$ sults from more than 10 studies suggest the risk of PD to be anywhere from 3 to 14 times higher in first-degree relatives of an affected individual as compared to the risk in members of unaffected families. ${ }^{9}$

To identify the genes contributing to PD susceptibility, researchers initially focused genetic analyses on families

Address correspondence and reprint requests to Nathan Pankratz, Indiana University School of Medicine, Department of Medical and Molecular Genetics, 975 Walnut Street, IB-130, Indianapolis, IN 46202. E-mail: nathan@pankratz.com. inheriting PD as a simple Mendelian disorder, either in an autosomal dominant or an autosomal recessive pattern. At present, five genes implicated in autosomal dominant forms of parkinsonism have been identified or localized (Table 1). The first gene $(S N C A)$, coding for alpha-synuclein, was identified by studying a large kindred from southern Italy, in which PD was pathologically confirmed. ${ }^{10}$ The same mutation in alpha-synuclein observed in the Italian kindred (Ala53Thr in exon 4) was later found in three Greek families, most of whom could trace their ancestry to a very small geographical area on the Peloponesos in southern Greece. ${ }^{10}$ Mutations in alpha-synuclein have been reported in eight additional individuals from six different families located in central and southwestern Greece, ${ }^{11}$ suggesting the presence of a founder mutation. ${ }^{12}$ Individuals with mutations in the alpha-synuclein gene have very similar clinical and pathological features to those with idiopathic PD, including a response to levodopa and the presence of Lewy bodies in the substantia nigra; however, the age at onset of PD in families with an alpha-synuclein mutation is significantly earlier than that typically observed in patients with idiopathic PD (mean 46 years). Despite intense scrutiny of pedigrees with familial PD, only two other mutations in alpha-synuclein have been reported. In a German family, a missense mutation altered an amino acid (Ala30Pro in exon 3), resulting in autosomal 
TABLE 1. Loci Linked to PD and Their Corresponding Genes (if Known)

\begin{tabular}{lccccc}
\hline Locus & $\begin{array}{c}\text { Chromosomal } \\
\text { Region }\end{array}$ & Causative Gene & Mode of Inheritance & Age of Onset & Reference No. \\
\hline PARK1 & $4 \mathrm{q} 21-23$ & $\alpha$-synuclein $(S N C A)$ & AD & Middle & 10 \\
PARK2 & $6 \mathrm{q} 25-27$ & parkin & AR & Juvenile & 25 \\
PARK3 & $2 \mathrm{p} 13$ & & AD & Typical & 21 \\
PARK5 & $4 \mathrm{p} 14$ & UCH-L1 & Apparent AD & Middle & 47 \\
PARK6 & $1 \mathrm{p} 35-\mathrm{p} 36$ & & AR & Early & 39 \\
PARK7 & $1 \mathrm{p} 36$ & DJ-1 & AR & Early & 41 \\
PARK8 & $12 \mathrm{p} 11-\mathrm{q} 13$ & & AD & Middle & 22 \\
Nurr1 & $2 \mathrm{q} 22-23$ & NR4A2 & Apparent AD & Typical & 65 \\
Synphilin-1 & $5 \mathrm{q} 23$ & SNCAIP & Apparent AD & Typical & 54 \\
Mitochondria & & NADH complex I & Mitochondrial & Typical & 66 \\
\hline
\end{tabular}

*Juvenile (mean age of onset $<20$ years); Early (mean age of onset 20-45 years); Middle (mean age of onset 46-60 years); Typical (mean age of onset $\geq 60$ years).

$\mathrm{AD}=$ autosomal dominant; $\mathrm{AR}=$ autosomal recessive .

dominant PD. ${ }^{13}$ More recently, a family was identified with a triplication of a large region that contained the alpha-synuclein gene. ${ }^{14}$ No other mutations in the alphasynuclein gene have been identified in the large number of patients with sporadic or familial PD that have been screened. ${ }^{15-18}$ Therefore, it appears that alpha-synuclein is not a major risk factor in familial PD.

Animal models have been developed to further study the role of alpha-synuclein in PD. Mice expressing the initially reported Ala53Thr human alpha-synuclein mutation exhibit late-onset neurodegeneration, motor dysfunction, and alpha-synuclein aggregation in the brain. ${ }^{19}$ In Drosophila models, expression of normal and mutated alpha-synuclein has also resulted in many features of PD, including motor deficits, specific degeneration, and interneuronal inclusions. ${ }^{20}$

Studies are ongoing to identify additional genes contributing to Mendelian forms of PD. Genetic analyses have detected linkage to chromosome $2 \mathrm{p} 13$ in a sample of families segregating an autosomal dominant form of PD (PARK3), although the responsible gene has not yet been identified..$^{21}$ Families linking to the PARK3 locus have clinical symptoms similar to typical, idiopathic PD, with a mean age at onset of 59 years of age and Lewy body pathology. All of the families linked to PARK3 are of German ancestry, and two of these families share a common haplotype, suggesting a possible founder effect. The causative mutation in these families also appears to have a reduced penetrance, perhaps less than $40 \%$, raising the possibility that this locus might also play role in sporadic PD.

The PARK8 locus has been linked to chromosome 12p11.2-q13.1 in a large Japanese family with autosomal dominant parkinsonism. ${ }^{22}$ The clinical features are typical of idiopathic PD, including a response to levodopa; however, the mean age at onset is slightly younger than in the more common forms of disease, with an average age of onset of 51 years. A common disease haplotype was found among all 15 affected individuals in the family. However, eight unaffected family members had also inherited the disease haplotype, suggesting a disease mutation with lower penetrance that might be mediated by other genetic or environmental factors. Autopsy reports of four affected individuals in the family showed "pure nigral degeneration," although Lewy bodies were not observed. ${ }^{22}$

Unlike many common disorders with complex patterns of disease inheritance, families have been identified with autosomal recessive as well as autosomal dominant disease susceptibility (Table 1). Autosomal recessive juvenile parkinsonism (AR-JP) is a distinct clinical and genetic entity within familial PD. It is characterized by typical PD features and an early age at onset ( $<40$ years), slow disease progression, sustained response to levodopa, early and often severe levodopa-induced complications, hyper-reflexia, and mild dystonia that is primarily in the feet. ${ }^{23-24}$ Of the genes implicated in familial PD, the largest number of mutations has been found in the parkin gene ${ }^{25}$ and mutations in this gene might account for PD in as many as 50\% of familial patients with AR-JP. ${ }^{26}$

Unlike the other genes found to cause PD, among which only a few mutations have been found in a small number of families, many different mutations have been reported in the parkin gene. These have included point mutations and exon rearrangements, including both deletions and duplications. ${ }^{25,27-36}$ Recently, several studies have reported that a single mutation in the parkin gene may increase susceptibility to disease or may even manifest in an autosomal dominant pattern of disease inheritance. For example, a large pedigree has been reported with adult-onset, clinically typical tremor-dominant parkinsonism, segregating a parkin mutation in an autosomal dominant manner. ${ }^{37}$ In another study, Lewy body pathology typical of idiopathic PD was found at autopsy in a proband from a kindred with a single parkin mutation. ${ }^{38}$ In a large sample of adult-onset PD sibling pairs, parkin mutations were found even among individuals 
with an age of onset of 60 or older. The mutations appear to act in a dose-dependent manner on the age of disease onset. Thus, individuals with a mutation in both parkin alleles had the earliest average age of onset, those with a mutation in only one allele had an intermediate age of PD onset, and those subjects without any mutation in the gene had the latest average age of onset. ${ }^{27}$

Additional loci resulting in autosomal recessive PD have been reported. Studies in a large Sicilian family segregating an autosomal recessive form of PD and having a relatively early age of PD onset detected linkage to chromosome 1p35-36 (PARK6). ${ }^{39}$ Although the causative gene has not yet been identified, linkage has since been observed in eight additional families from throughout Europe. ${ }^{40}$ Some of the typical features of AR-JP, such as dystonia and the improvement of symptoms after sleep, were not present in these families. However, in family members with late-onset PD, the clinical presentation of symptoms was identical to that of idiopathic PD. Although there was at least one individual in each of the linked families with an age at onset of younger than 45 , there was extensive variability in the age of diseaseonset among family members, with one individual having disease-onset at 68 years of age. Consanguinity was detected in one of these families, and homozygosity mapping was used to narrow the critical chromosomal region from $12.5 \mathrm{cM}$ (centimorgans) to $9 \mathrm{cM}$. Penetrance of the causative gene appears to be high.

Using a consanguineous pedigree from a genetically isolated population in the southwestern region of the Netherlands, a second locus on chromosome $1 \mathrm{p}$ was identified (PARK7). ${ }^{41}$ The gene underlying this linkage was recently determined to be $D J-1,{ }^{42}$ which was previously associated with several different biological processes. It was first reported as an oncogene, ${ }^{43}$ but it is also involved in the fertilization process of the rat and mouse. ${ }^{44-45}$ DJ-1 was more recently identified as a hydroperoxide-responsive protein that shifts to a more acidic isoform under oxidative conditions. Thus, it appears that DJ-1 functions as a sensor for oxidative stress. ${ }^{46}$

Two types of mutations in $D J-1$ have been found in patients with PD. ${ }^{42}$ One is a deletion of several of its exons, which prevents the synthesis of the protein. The other is a point mutation at a highly conserved residue (Leu166Pro) that makes the protein dramatically less stable and promotes degradation through the ubiquitinproteasome system, thereby reducing the amount of DJ-1 to low or absent levels. ${ }^{42}$

Most of the genes found to be mutated in PD have played a role in the ubiquitin-proteasome system. Therefore, extensive evaluation of several of the genes encoding proteins important in this pathway has been performed in samples from PD patients. As a result, a mutation in the ubiquitin C-terminal hydrolase-L1 $(U C H-L 1)$ gene (Ile93Met in exon 4) was identified in a single sibling pair with PD. ${ }^{47}$ After this report, the $U C H-L 1$ gene was examined in many different samples; however, no other patients with PD were identified with this or any other mutation in the UCH-L1 gene. This finding suggests that the observed change in the amino acid might be due to a polymorphism, and is not a disease-producing mutation. Despite the failure to identify any additional $U C H-L 1$ mutations, this gene remains a compelling candidate gene for PD for several reasons. First, studies have shown that this mutation causes a 50\% reduction in enzymatic activity when it is expressed in Escherichia coli. ${ }^{48}$ Second, UCH-L1, found throughout the brain, belongs to a family of de-ubiquitinating enzymes and therefore plays an important role in the labeling of abnormal proteins in the ubiquitin-proteasome system. ${ }^{49}$ Therefore, it is possible that reduced labeling and impaired clearance of abnormal proteins could lead to the neurodegeneration seen in PD.

Synphilin-1 (SNCAIP) is another gene that has been implicated in the pathogenesis of PD. Similar to an isoform of alpha-synuclein, it is a substrate of the gene product of parkin ${ }^{50}$ the ubiquitin E3 ligase that plays a role in the ubiquitin-proteasome system that clears abnormal proteins from the cell. Furthermore, it has been shown to interact directly with alpha-synuclein and is found, along with parkin and alpha-synuclein, in Lewy bodies. Modest evidence of linkage to the region of chromosome $5 \mathrm{q}$ that contains synphilin-1 has also been identified in the genome scans of three independent studies. ${ }^{51-53}$ Recently, the same mutation (R621C) was reported in two apparently sporadic patients with late-onset idiopathic PD (ages of onset, 63 and 69 years). ${ }^{54}$ This mutation was the only polymorphism found in 328 German familial and sporadic patients that was not seen in 351 control subjects. Both patients with this mutation reported no family history for PD. However, for five of the six microsatellite markers genotyped in the chromosomal region around the synphilin-1 gene, both patients shared the same rare alleles, which suggests that this variant was inherited from a common ancestor. Functional studies of the protein showed that mutant synphilin-1 can form cytoplasmic inclusions in transfected cells and that cells transfected with the R621C polymorphism are more susceptible to apoptosis than cells expressing wild-type synphilin-1.

The study of families segregating Mendelian forms of PD has been critical to many of the recent scientific advances in the field of PD research; however, only a small proportion of individuals with PD have mutations in these genes. Rather, most individuals with PD have a more limited family history of the disease and are far more likely to have inherited polymorphisms in disease susceptibility genes that increased the likelihood of developing PD. Studies designed to identify these PD susceptibility genes typically use families in which multiple 
members are diagnosed with PD, but who also do not have an obvious mode of disease inheritance.

Only two of the four studies that have reported genome screen results to identify PD susceptibility genes have reached statistical significance. The first study analyzed a unique sample: the relatively isolated and homogeneous population of Iceland. ${ }^{53}$ Using 117 affected individuals, they reported linkage to a region on chromosome $1 \mathrm{p} 32$ that they named PARK10. No evidence of linkage near the centromere of chromosome 1 has been reported in any of the other three PD family studies, indicating that perhaps this putative gene occurs at high frequency only in the Icelandic population. The second significant linkage came from a more heterogeneous sample ascertained from throughout North America. ${ }^{55} \mathrm{~A}$ subset of this sample that met the strict diagnostic criteria of the study and also had a stronger family history of PD yielded strong evidence of linkage to chromosome 2q36-37. Importantly, in these families, the gene appeared to act in an autosomal dominant inheritance pattern. Other chromosomes have been nominated in various studies of late-onset PD families. These include suggestive evidence of linkage to the $\mathrm{X}$ chromosome ${ }^{55}$ and chromosomes $5 q$ and $17 q$, near the tau gene. ${ }^{52}$

PD has wide variability in the age at disease onset, and various genes may contribute to disease susceptibility and to age at onset of disease. Three of the four family studies have also performed genetic analyses to identify genes that influence when an individual develops PD. Interestingly, two of the studies have their strongest linkage finding at the PARK3 locus on chromosome $2 \mathrm{p}^{56-57}$ The third study used a somewhat different approach by including in the model the age at exam of unaffected relatives. ${ }^{58}$ Their strongest linkage finding was on chromosome $1 \mathrm{p}$, near the susceptibility locus identified in the Icelandic population.

Several research groups have sought to identify PD susceptibility genes via the completion of populationbased case-control association studies of candidate genes, identified on the basis of their involvement in the dopamine pathway. Known genes investigated via association studies include the monoamine oxidase $\mathrm{B}$, dopamine D2 receptor, CYP2D6, CYP1A1, N-acetyltransferase 2, DAT1, and glutathione $S$-transferase M1 genes. ${ }^{59-61}$ Unfortunately, the few results from studies that found significant association between a candidate gene and PD have failed to replicate in other samples. This is most likely attributable to the susceptibility of association studies to yield spurious positive results due to population phenomena other than a causative relation (or close physical proximity) between the polymorphism being tested and a disease-causing mutation. ${ }^{62}$

There has been one association study that eventually led to an identified mutation in the candidate gene. Xu et al. ${ }^{63}$ reported that an increase in homozygosity of a vari- ant in the Nurr1 gene was associated with PD. More recently, an additional study on an independent sample suggested that heterozygosity for this polymorphism conferred an increased risk for PD. ${ }^{64}$ Subsequently, Le et al. ${ }^{65}$ described two distinct mutations in exon 1 in 10 individuals with familial PD. The age at onset of disease and the clinical features of these 10 individuals did not differ from those of individuals with typical PD. Nurr1 mRNA levels were significantly decreased in transfected cell lines with the mutation, compared with those without the mutation, as well as in the lymphocytes of the affected individuals. Furthermore, expression levels of the dopamine biosynthesis enzyme tyrosine hydroxylase were also markedly decreased in the transfected cells with the mutations compared with the wild type. These data suggest that dopaminergic dysfunction can result from mutations in Nurr1.

Mitochondrial dysfunction, particularly with regard to complex I of the electron transport chain, has been implicated in the pathogenesis of PD. Because a majority of mitochondrial DNA is dedicated to the reduced nicotinamide adenine dinucleotide complex I enzyme, van der Walt et al. ${ }^{66}$ tested the hypothesis that mtDNA variation contributes to PD expression. Ten single-nucleotide polymorphisms that define the European mtDNA haplogroups were genotyped for white individuals with PD and for matched control subjects. They found that individuals with either haplogroup J or K had a significantly lower risk of PD as compared with individuals carrying the most common haplogroup, H. These results suggest that variation in complex I proteins is an important risk factor in PD susceptibility among white individuals.

\section{TRANSLATION OF GENETIC INFORMATION TO CLINICAL PD}

With the identification of genes that are implicated in the causation of PD, it is now possible to ask how this information will impact the many patients diagnosed with this neurodegenerative disease. The answer to this question has several parts that have both short-term and long-term implications. In the short term, the direct clinical impact of the identification of alpha-synuclein, par$k i n$, and $D J-1$ is quite limited. A relatively small number of families have been found with mutations in these genes, and therefore their discovery is unlikely to have a broad impact on the millions of individuals worldwide suffering from sporadic PD. In the long term, the discovery of these genes mutated in PD is extremely important for our understanding of the biological pathways altered in PD.

Several of the genes mutated in PD appear to play a role in the ubiquitin-proteasome system. As a result, the pathway has been increasingly indicted, via several complementary lines of evidence, as playing a causative role 
in the development of PD. First, it is responsible for clearing proteins, such as misfolded alpha-synuclein and synphilin-1, from the cell, and secondly the parkin gene, which encodes a ubiquitin E3 ligase, and UCH-L1 are two of the enzymes that make up this pathway. Evidence of decreased enzymatic activity in the affected parts of the brains of patients with $\mathrm{AR}-\mathrm{JP}^{67}$ and the observation that mutations in parkin lead to an accumulation of nonubiquitinated proteins in dopamine neurons ${ }^{68-70}$ suggest that the impairment of the ubiquitin-proteasome system and the resulting toxicity of poorly degraded proteins could be the cause of PD in these individuals. There is also evidence that the crosslinking and polymerization of proteins necessary to form insoluble aggregates and inclusion bodies cannot occur if the proteins are not ubiquitinated. ${ }^{68,71,72}$ This could account for the lack of Lewy bodies in patients with $\mathrm{AR}-\mathrm{JP}$ and also gives further credence to the hypothesis that Lewy bodies are, in fact, protective. If these intracellular inclusions protect the surrounding cells by removing the toxicity of the involved proteins, their absence in AR-JP might explain the rapid degeneration and early age at onset in this subset of PD patients.

Another PD causative gene, $D J-1$, is similarly involved in the ubiquitin-proteasome pathway for two reasons. First, mutations leading to misfolded DJ-1 might overload the ubiquitin-proteasome system and decrease its effectiveness. ${ }^{73}$ Second, DJ-1 is thought to be involved in oxidative damage, which is known to increase the rate of aggregation of alpha-synuclein.

Oxidative stress is a unifying factor in the current theories of PD pathogenesis, because it links genetic and potential environmental factors in the onset and progression of the disease. Those environmental toxins that have the strongest association with PD phenotypes either cause high amounts of oxidative stress, such as with MPTP (1-methyl-4-phenyl-1,2,5,6-tetrahydropyridine) and rotenone, or directly increase the rate of alphasynuclein aggregation, as with copper and other heavy metals. ${ }^{74}$ Furthermore, the aggregation of alphasynuclein itself can cause oxidative stress, ${ }^{75}$ and oxidative stress can in turn cause conformational changes in alpha-synuclein. ${ }^{76}$

Alpha-synuclein, however, is not limited strictly to dopaminergic neurons, and therefore its accumulation cannot fully explain the specificity often seen in disease pathogenesis. The one obvious difference between the cells in the substantia nigra and other cells in the brain expressing this protein is the presence of dopamine. Recent experiments have shown that the overexpression of alpha-synuclein results in apoptotic cell death only in dopaminergic cells and that suppressing endogenous dopamine expression in these cells completely inhibits alpha-synuclein-induced apoptosis. ${ }^{77}$ These dopaminergic cells could also be saved through the addition of antioxidants, which not only provides further evidence that reactive oxygen species are leading to cell death but also suggests that the combination of increased alphasynuclein and dopamine is necessary for degeneration. The exact mechanism of cell death is not known, but the toxicity of DOPAL, the monoamine oxidase metabolite of dopamine, may play a role. Anything that would increase cytosolic dopamine, and therefore this toxic metabolite, could explain the selective degeneration seen in $\mathrm{PD}^{78}$ If increased alpha-synuclein affects dopamine reuptake, as some studies have already shown, ${ }^{79-80}$ it would go far to explain this deadly combination.

Thus, in less than 5 years, the identification of genes resulting in PD has revolutionized the theories underlying disease pathogenesis. In the past, simply understanding the molecules involved in disease pathogenesis has allowed new therapies to be developed. For example, insulin has proven to be an important treatment for many diabetics, and administration of levodopa can ameliorate symptoms of PD. Thus, even if mutations in alphasynuclein, parkin, or DJ-1 are not central to PD, the molecules themselves are, and the next generation of PD treatments will no doubt be based on research that would not have been possible without the identification of that first rare mutation in alpha-synuclein.

\section{GENE TESTS FOR PD}

Similar to the experience in many neurodegenerative disorders, it is to be expected that the public will demand the application of new PD genetic discoveries to clinical practice. The molecular tests of these new PD genes can be used in several ways. In some instances, molecular testing of a disease gene may be performed to verify a clinical diagnosis in an individual manifesting only mild or atypical disease symptoms. In other cases, a molecular test may be requested for the purpose of presymptomatic or prenatal testing. Fortunately, there are several diseases to which we can turn to gain valuable insight toward the appropriate application of molecular diagnostic tests in PD. ${ }^{81}$

Huntington disease was one of the first disorders to be mapped to a chromosome using modern technology, although the subsequent identification of the disease gene required a decade of intensive research. For this typically adult-onset, neurodegenerative disorder, clinicians, geneticists, and ethicists met to develop consensus documents regarding the appropriate use of molecular testing for this incurable disease. The basic principles included: 1) the molecular test could be used for diagnosis among patients with clinical manifestation of disease, 2) presymptomatic and prenatal molecular testing would only be performed in conjunction with a genetic counselor who would follow a strict protocol that included both pretest and post-test counseling. These guidelines, which are detailed in the paper by Dr. Myers in this issue, can 
also provide an important framework for genetic testing in PD; however, there are several important distinctions. First, Huntington disease is due to mutations in a single gene. In contrast, at least three genes have been identified which, when mutated, can result in PD. Furthermore, there are many individuals who have not inherited a Mendelian form of PD and, therefore, disease risk is likely due to the combined effects of genetic and environmental factors. Thus, counseling in PD is much more complex.

Alzheimer disease can provide a model for the complexity observed in $\mathrm{PD}{ }^{82}$ Similar to $\mathrm{PD}$, families with Alzheimer disease have been identified that are segregating an early-onset, Mendelian form of the disease. In the majority of these early-onset, primarily autosomal dominant pedigrees, the disease is due to a mutation in one of three genes: presenilin 1 (PS1), presenilin 2 (PS2), or amyloid precursor protein (APP). Guidelines for gene testing similar to those implemented for Huntington disease have been recommended for all molecular testing. Due to the rarity of families with mutations in either PS2 or APP, commercial molecular testing is only available for PS1.

In an additional parallel with PD, extensive studies have been performed in families having multiple members with later-onset $\mathrm{AD}$. Analyses in these families, as well as further studies in other samples, have consistently demonstrated the importance of the apolipoprotein $\mathrm{E}$ (APOE) gene in disease risk. One allele of the APOE gene, APOE4, increases the risk of AD whereas a second allele, APOE2, appears to reduce the risk of AD. Importantly, variation in the APOE gene does not cause AD, but rather the gene acts as a susceptibility locus. To ensure that a diagnostic test would not be misused for this susceptibility gene, a consensus document was established to guide molecular testing of the APOE gene. Briefly, the recommendation was made that APOE molecular testing was appropriate as part of a clinical evaluation of an individual with dementia or memory loss; however, presymptomatic and prenatal molecular testing of the APOE gene was not appropriate, since the clinical implication of one or two APOE4 alleles was uncertain.

The lessons from Huntington disease and Alzheimer disease should guide us in the use of molecular testing in PD. With the rarity of alpha-synuclein mutations and the still unknown frequency of $D J-1$ mutations, great attention has been focused on testing of the parkin gene, particularly in those families with juvenile or early-onset PD. A molecular test has recently become available that will screen for a variety of mutations in the parkin gene. However, unlike testing in Huntington disease or Alzheimer disease, genetic counseling has not been required as part of molecular testing. This is extremely unfortunate and sets a poor precedent for future molecular testing.

At this time, about $50 \%$ of individuals with earlyonset, autosomal recessive PD may have a mutation in the parkin gene. Confirmatory testing of the parkin gene is indicated for individuals with onset of PD before age 40. Individuals with mutations in both parkin alleles have been found among those with onset over the age of $40 .{ }^{37}$ These cases were usually found in families with two or more affected siblings; however, it is likely that the number of individuals with two parkin mutations that have an onset over 40 years of age will be relatively small. However, it is difficult to assign a threshold of specific age at onset beyond which parkin testing is counterindicated. Therefore, parkin testing should be performed at the discretion of the treating physician.

Of concern are the studies that suggest that a single mutation in the parkin gene may be found among individuals with $\mathrm{PD}{ }^{27,37,38}$ This raises the possibility that a single mutation in the parkin gene may be sufficient for disease or may increase the risk of disease. It is also important to keep in mind that even when an inherited mutation is responsible for the disease, it is not necessarily one of the mutations being tested. Dozens of different mutations have already been reported for the parkin gene, and it is likely that they are not equally influential, with several potentially not having any clinical consequences at all. Thus, a positive test may not necessarily be associated with an increased risk of PD, and a negative parkin test does not exclude the risk of PD. It is likely that unaffected, first-degree relatives of individuals with two parkin mutations will wish to undergo parkin testing to better assess their risk of PD. Unfortunately, the interpretation of their parkin results and their risk for PD cannot be definitively determined until additional studies are performed that assess the penetrance of a single parkin mutation. Until these issues are resolved, it would appear premature to offer presymptomatic parkin testing, particularly without requiring any genetic counseling.

\section{SUMMARY}

There has been substantial progress over the past decade in our understanding of the genetics of PD. This has included the identification of at least three genes which, when mutated, can result in PD. Furthermore, there are several additional chromosomal regions in which a disease gene is yet to be identified. Studies in multiplex PD families have also been actively pursued and have provided findings that may ultimately lead to the identification of genes that act as susceptibility or protective factors for disease risk. These genetic discoveries have substantially altered our models of PD pathogenesis and led to the realization of the importance of the ubiquitinproteasome system. Over the next few years, it is anticipated that additional PD causative and susceptibility genes will be identified. Their discovery poses challenges as we attempt to transfer these research findings to 
clinical practice. To date, only a diagnostic test for parkin has been developed; however, the interpretation of test results are likely to be ambiguous and it is recommended that presymptomatic testing be delayed until more is learned about the frequency, penetrance, and risk assessment of parkin mutations.

Acknowledgments: Supported by National Institutes of Health Grant R01 NS37167.

\section{REFERENCES}

1. Gowers WR. A Manual of the Diseases of the Nervous System. 2nd ed. Philadelphia: Blakiston, 1902.

2. Leroux P-D. Contribution a l'etude des causes de laparalysie agitante. In: These de Paris, 1880.

3. Scarpalezos S. Sur la notion d'heredite similaire dans la maladie de Parkinson. Rev Neurol 80:184, 1948.

4. Tanner CM, Ottmann R, Goldman SM, Ellenberg J, Chan P, Mayeux R et al. Parkinson's disease in twins: an etiologic study. JAMA 281:341-346, 1999.

5. Martin WE, Young WI, Anderson VE. Parkinson's disease: a genetic study. Brain 96:495-506, 1973.

6. Barbeau A, Roy M, Boyer L. Genetic studies in Parkinson's disease. Adv Neurol 40:333-339, 1984.

7. Alonso ME, Otero E, D'Regules R, Figueroa HH. Parkinson's disease: a genetic study. Can J Neurol Sci 13:248-251, 1986.

8. Duvoisin RC, Johnson WG. Hereditary Lewy-body parkinsonism and evidence for a genetic etiology of Parkinson's disease. Brain Pathol 2:309-320, 1992.

9. Pankratz N, Nichols WC, Uniacke SK, Halter C, Murrell J, Rudolph A et al. Genome-wide linkage analysis and evidence of gene-by-gene interactions in a sample of 362 multiplex Parkinson disease families. Hum Mol Genet 12:2599-2608, 2003.

10. Polymeropoulos MH, Lavedan C, Leroy E, Ide SE, Dehejia A, Dutra A et al. Mutation in the alpha-synuclein gene identified in families with Parkinson's disease. Science 276:2045-2047, 1997.

11. Bostantjopoulou S, Katsarou Z, Papadimitriou A, Veletza V, Hatzigeorgiou G, Lees A. Clinical features of parkinsonian patients with the alpha-synuclein (G209A) mutation. Mov Disord 16:10071013, 2001.

12. Gasser T. Genetics of Parkinson's disease. J Neurol 248:833-840, 2001.

13. Kruger R, Kuhn W, Muller T, Woitalla D, Graeber M, Kosel S et al. Ala30Pro mutation in the gene encoding alpha-synuclein in Parkinson's disease. Nat Genet 18:106-108, 1998.

14. Singleton A, Farrer M, Johnson J, Singleton A, Hague S, Kachergus J. Alpha-synuclein locus triplication causes Parkinson disease. Science 302:841, 2003.

15. Pastor P, Munoz E, Ezquerra M, Obach V, Marti MJ, Valldeoriola $\mathrm{F}$ et al. Analysis of the coding and the $5^{\prime}$ flanking regions of the alpha-synuclein gene in patients with Parkinson's disease. Mov Disord 16:1115-1119, 2001.

16. Chan P, Jiang X, Forno LS, Di Monte DA, Tanner CM, Langston JW. Absence of mutations in the coding region of the alphasynuclein gene in pathologically proven Parkinson's disease. Neurology 50:1136-1137, 1998.

17. Farrer M, Wavrant-De Vrieze F, Crook R, Boles L, Perez-Tur J, Hardy $\mathrm{J}$ et al. Low frequency of alpha-synuclein mutations in familial Parkinson's disease. Ann Neurol 43:394-397, 1998.

18. Vaughan JR, Farrer MJ, Wszolek ZK, Gasser T, Durr A, Agid Y et al. Sequencing of the alpha-synuclein gene in a large series of cases of familial Parkinson's disease fails to reveal any further mutations. The European Consortium on Genetic Susceptibility in Parkinson's Disease (GSPD). Hum Mol Genet 7:751-753, 1998.

19. Lee MK, Stirling W, Xu Y, Xu X, Qui D, Mandir AS et al. Human alpha-synuclein-harboring familial Parkinson's disease-linked Ala-53-Thr mutation causes neurodegenerative disease with $\alpha$-synuclein aggregation in transgenic mice. Proc Natl Acad Sci USA 99:8968-8973, 2002.
20. Feany MB, Bender WW. A Drosophila model of Parkinson's disease. Nature 404:394-398, 2000.

21. Gasser T, Müller-Myhsok B, Wszolek ZK, Oehlmann R, Calne DB, Bonifati V et al. A susceptibility locus for Parkinson's disease maps to chromosome 2p13. Nat Genet 18:262-265, 1998.

22. Funayama M, Hasegawa K, Kowa H, Saito M, Tsuji S, Obata F. A new locus for Parkinson's disease (PARK8) maps to chromosome 12p11,2-q13,1. Ann Neurol 51:296-301, 2002.

23. Yamamura Y, Sobue I, Ando K, Iida M, Yanagi T, Kondo C. Paralysis agitans of early-onset with marked diurnal fluctuation of symptoms. Neurology 23:239-244, 1973.

24. Ishikawa A, Tsuji S. Clinical analysis of 17 patients in 12 Japanese families with autosomal-recessive type juvenile Parkinsonism. Neurology 47:160-166, 1996.

25. Kitada T, Asakawa S, Hattori N, Matsumine H, Yamamura Y, Minoshima $\mathrm{S}$ et al. Mutations in the parkin gene cause autosomal recessive juvenile parkinsonism. Nature 392:605-608, 1998.

26. Lücking CB, Durr A, Bonifati V, Vaughan J, De Michele G, Gasser $T$ et al. Association between early-onset Parkinson's disease and mutations in the parkin gene. French Parkinson's Disease Genetics Study Group. N Engl J Med 342:1560-1567, 2000.

27. Foroud T, Uniacke SK, Liu L, Pankratz N, Rudolph A, Halter C et al. Heterozygosity for a mutation in the parkin gene leads to later onset Parkinson disease. Neurology 60:796-801, 2003.

28. Oliveira SA, Scott WK, Martin ER, Nance MA, Watts RL, Hubble JP et al. Parkin mutations and susceptibility alleles in late-onset Parkinson's disease. Ann Neurol 53:624-629, 2003.

29. Tan LC, Tanner CM, Chen R, Chan P, Farrer M, Hardy J et al. Marked variation in clinical presentation and age of onset in a family with a heterozygous parkin mutation. Mov Disord 18:758763, 2003.

30. Nichols WC, Pankratz N, Uniacke SK, Pauciulo MW, Halter C, Rudolph A et al. Linkage stratification and mutation analysis at the parkin locus identifies mutation positive, Parkinson disease families. J Med Genet 39:489-492, 2002.

31. Kann M, Jacobs H, Mohrmann K, Schumacher K, Hedrich K, Garrels J et al. Role of parkin mutations in 111 community-based patients with early-onset parkinsonism. Ann Neurol 51:621-625, 2002.

32. West A, Periquet M, Lincoln S, Lücking CB, Nicholl D, Bonifati $\mathrm{V}$ et al. Complex relationship between parkin mutations and Parkinson disease. Am J Med Genet 114:584-591, 2002.

33. Hedrich K, Marder K, Harris J, Kann M, Lynch T, Meija-Santana $\mathrm{H}$ et al. Evaluation of 50 probands with early-onset Parkinson's disease for parkin mutations. Neurology 58:1239-1246, 2002.

34. Lücking CB, Durr A, Bonifati V, Vaughan J, De Michele G, Gasser T et al. Association between early-onset Parkinson's disease and mutations in the parkin gene. French Parkinson's Disease Genetics Study Group. N Engl J Med 342:1560-1567, 2000.

35. Abbas N, Lücking CB, Ricard S, Durr A, Bonifati V, De Michele $\mathrm{G}$ et al. A wide variety of mutations in the parkin gene are responsible for autosomal recessive parkinsonism in Europe. French Parkinson's Disease Genetics Study Group and the European Consortium on Genetic Susceptibility in Parkinson's Disease. Hum Mol Genet 8:567-574, 1999.

36. Lücking CB, Abbas N, Durr A, Bonifati V, Bonnet AM, de Broucker $\mathrm{T}$ et al. Homozygous deletions in parkin gene in European and North African families with autosomal recessive juvenile parkinsonism. The European Consortium on Genetic Susceptibility in Parkinson's Disease and the French Parkinson's Disease Genetics Study Group. Lancet 352:1355-1356, 1998.

37. Klein C, Pramstaller PP, Kis B, Page CC, Kann M, Leung J et al. Parkin deletions in a family with adult-onset, tremor-dominant parkinsonism: expanding the phenotype. Ann Neurol 48:65-71, 2000.

38. Farrer M, Chan P, Chen R, Tan L, Lincoln S, Hernandez D et al. Lewy bodies and parkinsonism in families with parkin mutations. Ann Neurol 50:293-300, 2001.

39. Valente EM, Bentivoglio AR, Dixon PH, Ferraris A, Ialongo T, Frontali $\mathrm{M}$ et al. Localization of a novel locus for autosomal recessive early-onset parkinsonism, PARK6, on chromosome 1p35-p36. Am J Hum Genet 68:895-900, 2001.

40. Valente EM, Brancati F, Ferraris A, Graham EA, Davis MB, 
Breteler MM et al. PARK6-linked parkinsonism occurs in several European families. Ann Neurol 51:14-18, 2002.

41. van Duijn CM, Dekker MCJ, Bonifati V, Galjaard RJ, HouwingDuistermaat JJ, Snijders PJ et al. PARK7, a novel locus for autosomal recessive early-onset parkinsonism, on chromosome $1 \mathrm{p} 36$. Am J Hum Genet 69:629-634, 2001.

42. Bonifati V, Rizzu P, van Baren MJ, Schaap O, Breedveld GJ, Krieger E et al. Mutations in the DJ-1 gene associated with autosomal recessive early-onset parkinsonism. Science 299:256-259, 2003.

43. Nagakubo D, Taira T, Kitaura H, Ikeda M, Tamai K, Iguchi-Ariga SM et al. DJ-1, a novel oncogene which transforms mouse NIH3T3 cells in cooperation with ras. Biochem Biophys Res Commun 231: 509-513, 1997.

44. Wagenfeld A, Gromoll J, Cooper TG. Molecular cloning and expression of rat contraception associated protein 1 (CAP1), a protein putatively involved in fertilization. Biochem Biophys Res Commun 251:545-549, 1998.

45. Okada M, Matsumoto K, Niki T, Taira T, Iguchi-Ariga SM, Ariga $\mathrm{H}$. DJ-1, a target protein for an endocrine disrupter, participates in the fertilization in mice. Biol Pharm Bull 25:853-856, 2002.

46. Mitsumoto A, Nakagawa Y. DJ-1 is an indicator for endogenous reactive oxygen species elicited by endotoxin. Free Radic Res 35:885-893, 2001.

47. Leroy E, Boyer R, Auburger G, Leube B, Ulm G, Mezey E et al. The ubiquitin pathway in Parkinson's disease. Nature 395:451$452,1998$.

48. Wintermeyer P, Kruger R, Kuhn W, Muller T, Woitalla D, Berg D et al. Mutation analysis and association studies of the UCHL1 gene in German Parkinson's disease patients. NeuroReport 11:20792082, 2000.

49. Pickart CM. Ubiquitin in chains. Trends Biochem Sci 25:544-548, 2000.

50. Chung KK, Zhang Y, Lim KL, Tanaka Y, Huang H, Gao J et al. Parkin ubiquitinates the alpha-synuclein-interacting protein, synphilin-1: implications for Lewy-body formation in Parkinson disease. Nat Med 7:1144-1150, 2001.

51. Pankratz N, Nichols WC, Uniacke SK, Halter C, Rudolph A, Shults $\mathrm{C}$ et al. Genome screen to identify susceptibility genes for Parkinson disease in a sample without parkin mutations. Am J Hum Genet 71:124-135, 2002.

52. Scott WK, Nance MA, Watts RL, Hubble JP, Koller WC, Lyons K et al. Complete genomic screen in Parkinson disease: evidence for multiple genes. JAMA 286:2239-2244, 2001.

53. Hicks AA, Petursson H, Jonsson T, Stefansson H, Johannsdottir HS, Sainz J et al. A susceptibility gene for late-onset idiopathic Parkinson's disease. Ann Neurol 52:549-555, 2002.

54. Marx FP, Holzmann C, Strauss KM, Li L, Eberhardt O, Gerhardt $\mathrm{E}$ et al. Identification and functional characterization of a novel R621C mutation in the synphilin-1 gene in Parkinson's disease. Hum Mol Genet 12:1223-1231, 2003.

55. Pankratz N, Nichols WC, Uniacke SK, Halter C, Rudolph A, Shults $\mathrm{C}$ et al. Significant linkage of Parkinson disease to chromosome 2q36-37. Am J Hum Genet 72:1053-1057, 2003.

56. DeStefano AL, Lew MF, Golbe LI, Mark MH, Lazzarini AM, Guttman $\mathrm{M}$ et al. PARK3 influences age at onset in Parkinson disease: a genome scan in the GenePD study. Am J Hum Genet 70:1089-1095, 2002.

57. Pankratz N, Uniacke SK, Halter C, Rudolph A, Shults C, Conneallyu PM et al. Genes influencing Parkinson disease onset: replication of PARK3 and identification of novel loci. Neurology (in press)

58. Li YJ, Scott WK, Hedges DJ, Zhang F, Gaskell PC, Nance MA et al. Age at onset in two common neurodegenerative diseases is genetically controlled. Am J Hum Genet 70:985-993, 2002.

59. Mellick GD, Buchanan DD, McCann SJ, James KM, Johnson AG, Davis DR et al. Variations in the monoamine oxidase B (MAOB) gene are associated with Parkinson's disease. Mov Disord 14:219224, 1999.

60. Grevle L, Guzey C, Hadidi H, Brennersted R, Idle JR, Aasly J. Allelic association between the DRD2 TaqI A polymorphism and Parkinson's disease. Mov Disord 15:1070-1074, 2000.
61. Nicholl DJ, Bennett P, Hiller L, Bonifati V, Vanacore N, Fabbrini $\mathrm{G}$ et al. A study of five candidate genes in Parkinson's disease and related neurodegenerative disorders. European Study Group on Atypical Parkinsonism. Neurology 53:1415-1421, 1999.

62. Spielman RS, Ewens WJ. The TDT and other family-based tests for linkage disequilibrium and association. Am J Hum Genet 59: 983-989, 1996.

63. Xu PY, Liang R, Jankovic J, Hunter C, Zeng YX, Ashizawa T et al. Association of homozygous $7048 \mathrm{G} 7049$ variant in the intron six of Nurr1 gene with Parkinson's disease. Neurology 58:881-884, 2002.

64. Zheng K, Heydari B, Simon DK. A common NURR1 polymorphism associated with Parkinson disease and diffuse Lewy body disease. Arch Neurol 60:722-725, 2003.

65. Le WD, Xu P, Jankovic J, Jiang H, Appel SH, Smith RG et al. Mutations in NR4A2 associated with familial Parkinson disease. Nat Genet 33:85-89, 2003.

66. van der Walt JM, Nicodemus KK, Martin ER, Scott WK, Nance MA, Watts RL et al. Mitochondrial polymorphisms significantly reduce the risk of Parkinson disease. Am J Hum Genet 72:804$811,2003$.

67. Shimura H, Hattori N, Kubo S, Mizuno Y, Asakawa S, Minoshima $\mathrm{S}$ et al. Familial Parkinson disease gene product, parkin, is a ubiquitin-protein ligase. Nat Genet 25:302-305, 2000.

68. Shimura H, Schlossmacher MG, Hattori N, Frosch MP, Trockenbacher A, Schneider R et al. Ubiquitination of a new form of alpha-synuclein by parkin from human brain: implications for Parkinson's disease. Science 293:263-269, 2001.

69. Zhang Y, Gao J, Chung KK, Huang H, Dawson VL, Dawson TM. Parkin functions as an E2-dependent ubiquitin-protein ligase and promotes the degradation of the synaptic vesicle-associated protein, CDCrel-1. Proc Natl Acad Sci USA 97:13354-13359, 2000.

70. Imai Y, Soda M, Inoue H, Hattori N, Mizuno Y, Takahashi R. An unfolded putative transmembrane polypeptide, which can lead to endoplasmic reticulum stress, is a substrate of Parkin. Cell 105: 891-902, 2001.

71. Johnston JA, Ward CL, Kopito RR. Aggresomes: a cellular response to misfolded proteins. J Cell Biol 143:1883-1898, 1998.

72. Cummings CJ, Reinstein E, Sun Y, Antalffy B, Jiang Y, Ciechanover A et al. Mutation of the E6-AP ubiquitin ligase reduces nuclear inclusion frequency while accelerating polyglutamine-induced pathology in SCA1 mice. Neuron 24:879-892, 1999.

73. Miller DW, Ahmad R, Hague S, Baptista MJ, Canet-Aviles R, McLendon C et al. L166P mutant DJ-1, causative for recessive Parkinson's disease, is degraded through the ubiquitin-proteasome system. J Biol Chem 278:36588-36595, 2003.

74. Uversky VN, Li J, Fink AL. Metal-triggered structural transformations, aggregation, and fibrillation of human alpha-synuclein. A possible molecular NK between Parkinson's disease and heavy metal exposure. J Biol Chem 276:44284-442896, 2001.

75. Turnbull S, Tabner BJ, El-Agnaf OM, Moore S, Davies Y, Allsop D. Alpha-synuclein implicated in Parkinson's disease catalyses the formation of hydrogen peroxide in vitro. Free Radic Biol Med 30:1163-11670, 2001.

76. Ischiropoulos H. Oxidative modifications of alpha-synuclein. Ann NY Acad Sci 991:93-100, 2003.

77. Xu J, Kao SY, Lee FJ, Song W, Jin LW, Yankner BA. Dopaminedependent neurotoxicity of alpha-synuclein: a mechanism for selective neurodegeneration in Parkinson disease. Nat Med 8:600606, 2002.

78. Burke WJ. Recent advances in the genetics and pathogenesis of Parkinson's disease. Neurology 59:1118, 2002.

79. Wersinger C, Prou D, Vernier P, Sidhu A. Modulation of dopamine transporter function by alpha-synuclein is altered by impairment of cell adhesion and by induction of oxidative stress. FASEB $J$ 17(14):2151-3, 2003.

80. Lee FJ, Liu F, Pristupa ZB, Niznik HB. Direct binding and functional coupling of alpha-synuclein to the dopamine transporters accelerate dopamine-induced apoptosis. FASEB J 15:916-926, 2001.

81. McCusker EA. The specialist neurologist and the "new genetics". Med J Aust 179:167-169, 2003.

82. Greely HT. Special issues in genetic testing for Alzheimer disease. Genet Test 3:115-119, 1999. 